УДК 342.9

DOI https://doi.org/10.32849/2663-5313/2020.5.25

Олександр Мамалуй,

канд. юрид. наук,

суддя Верховного Суду України

\title{
МАТЕРІАЛЬНІ ТА ПРОЦЕСУАЛЬНІ АСПЕКТИ СУДОВИХ ПРОВАДЖЕНЬ ІЗ ВИРІШЕННЯ ПОДАТКОВИХ СПОРІВ
}

У науковій роботі автором визначено зміст $і$ співвідношення матеріального та процесуального аспекту в межах судових проваджень з вирішення податкових спорів, мету матеріальних і проиесуальних аспектів вирішення податкових спорів у судовому порядку. Окрему увагу приділено дослідженню сукупності прощедур розгляду справ щодо вирішення податкових спорів, детально регламентованих адміністративним процесуальним законодавством, що характеризуються стадійністю та взаємозумовленістю. Визначено особливості судових проваджень із вирішення податкових спорів. Наведено класифікацію матеріальних аспектів із вирішення податкових спорів за критерієм закріплення матеріальних аспектів судових проваджень із вирішення податкових спорів у нормативно-правових актах. У процесі дослідження визначено змістове наповнення поняття «податковий спір», а також встановлено, які саме діяння здатні спричинити податковий спір, які суб'єкти можуть бути сторонами такого спору, які органи мають право приймати остаточне рішення в умовах урегулювання податково-правового конфлікту. У науковому дослідженні наголошено на існуванні податкових правовідносин як базового матеріального аспекту судових проваджень із вирішення податкових спорів, оскільки за відсутності таких відносин між сторонами порушення процесу є неможливим. Під час дослідження поняття «податковий спір і його основних характеристик здійснено розмежування податкових спорів за критерієм судової практики на спори з питань права, спори з питань факту і процедурні спори. Розглядаючи питання про приналежність тих чи інших норм до процесуальних, автор доходить висновку про наявність у чинному податковому законодавстві норм, які мають змішану правову природу, тобто одна й та сама норма одночасно може розглядатись як матеріальна, так і процесуальна, адже мають матеріальне підгрунтя виходячи при иьому із процесуальних фактів.

Ключові слова: податкові спори, судові провадження, матеріальні аспекти вирішення податкових спорів, процесуальні аспекти вирішення податкових спорів.

Кожен судовий процес складається із взаємоузгоджених стадій, які включають у себе відповідну сукупність процедур. Спеціалізація суду визначає особливості окремого процесу - адміністративного, цивільного, кримінального, господарського. Процес є формою вирішення конфліктної правової ситуації. Змістове наповнення процесу визначається матеріальними правовідносинами, що попередньо, тобто до порушення процесу, сформувались між сторонами. Саме матеріальні правовідносини є фундаментом процесуальних правовідносин, оскільки з них випливає спір, формується предмет спору, який тим самим зумовлює вибір конкретного судового органу, уповноваженого розглядати справу.

Матеріальні аспекти судових проваджень формуються на основі норм матеріального права, тобто регуляторів, за допомогою яких держава здійснює вплив на відповідну сферу суспільних відносин. У зв'язку з цим матеріальними аспектами судових проваджень з вирішення податкових спорів є матеріальні податкові правовідносини, на основі яких виникає податковий спір, а також норми права, закріплені у конституційному, податковому та адміністративному процесуальному законодавстві, спрямовані на регулювання податкових відносин у контексті процесуальних можливостей захисту прав та/або законних інтересів платників податків і держави. Матеріальні аспекти мають на меті визначення змісту прав та обов'язків суб'єктів права і відповідають на питання: що треба зробити для реалізації цих прав і обов'язків?

Процесуальні аспекти судових проваджень охоплюють сукупність окремих процедур розгляду справ щодо вирішення податкових спорів, детально регламентованих адміністративним процесуальним законодавством, що характеризуються стадійністю та взаємозумовленістю, й тільки у своїй єдності формують процес. Такі аспекти відповідають на питання: як, яким чином, у якому порядку права та обов'язки можуть і мають бути реалізовані. 
У контексті розглядуваного питання слід зазначити, що за критерієм закріплення матеріальних аспектів судових проваджень із вирішення податкових спорів у нормативноправових актах такі аспекти поділяються на:

1) ті, що закріплені у Податковому кодексі України (далі - ПК України) або інших нормативно-правових актах, спрямованих на регулювання податкових правовідносин (наприклад, право платника оскаржити рішення, дію або бездіяльність контролюючого органу у судовому порядку);

2) ті, що закріплені у Кодексі адміністративного судочинства України (далі - КАС України).

Процесуальні аспекти судових проваджень із вирішення податкових спорів передбачені у КАС України.

Судові провадження із вирішення податкових спорів мають свої особливості. Тому перш ніж перейти до безпосередньої характеристики матеріальних та процесуальних аспектів таких судових проваджень, варто визначити змістове наповнення поняття «податковий спір», а також встановити, які саме діяння здатні спричинити податковий спір, які суб'єкти можуть бути сторонами такого спору, які органи мають право приймати остаточне рішення в умовах урегулювання податково-правового конфлікту.

Ні ст. 14 Податкового кодексу України, ні будь-якою іншою статтею цього нормативного акта поняття «податковий спір» не передбачено, що зумовлює звернення до теоретичних надбань із порушеної проблеми.

Загальновизнаним є той факт, що будьякий спір виникає між декількома (двома або більше) сторонами. Джерелом спору є відносини, які попередньо, тобто до початку так званого «спірного стану», сформувались між сторонами. Якщо відносини мають правове підгрунтя, тобто складаються на основі норми права, вони набувають статусу правовідносин. Податкові правовідносини характеризуються не тільки загальними ознаками, що притаманні будь-яким правовідносинам, а й спеціальними: виникають на основі норм податкового права, завжди є владно-майновими, одним із суб'єктів завжди виступає держава в особі уповноважених податкових органів, виникають у процесі фінансової діяльності держави, характеризуються нерівністю положення їх учасників, тобто грунтуються на підпорядкуванні однієї сторони іншій [1].

Наведене дає підстави виокремити основну особливість податкових спорів, а саме те, що вони виникають із податкових правовідносин, які за своєю суттю є публічно-правовими, що зумовлює специфіку і стосовно учасників таких відносин, і щодо порядку вирішення юридичних конфліктів між ними. Саме податкові правовідносини є базовим матеріальним аспектом судових проваджень із вирішення податкових спорів, оскільки за відсутності таких відносин між сторонами порушення процесу є неможливим.

Як указано у п. 1.1 ст. 1 ПК України, цей Кодекс регулює відносини, що виникають у сфері справляння податків і зборів, зокрема визначає вичерпний перелік податків та зборів, що справляються в Україні, та порядок їх адміністрування, платників податків та зборів, їх права та обов'язки, компетенцію контролюючих органів, повноваження і обов'язки їх посадових осіб під час адміністрування податків, а також відповідальність за порушення податкового законодавства [2]. Із цього видається, що суб'єктами податкових відносин, а отже, й потенційними сторонами податкового спору, є управомочена та зобов'язана особи - контролюючий орган і платник податку.

Слід погодитись з ученим В.В. Тильчиком, який під поняттям «податковий спір» розуміє форму вирішення конфліктів (протиріччя інтересів) у сфері податкових правовідносин, яка носить публічний характер, виникає між державою і платниками податків чи іншими учасниками податкових правовідносин 3 приводу застосування норм податкового права, вирішуються уповноваженим юрисдикційним органом у процесуальному порядку [3].

3 точки зору розмежування податкових спорів за критерієм судової практики варто звернутись до наукової думки І.В. Цвєткова, який виділяє такі три групи спорів:

1) спори з питань права - спори, що зумовлені різним тлумаченням чи застосуванням окремих норм матеріального права;

2) спори 3 питань факту - спори, пов'язані з різною оцінкою фактичних обставин справи;

3) процедурні спори - спори, пов'язані 3 порушенням встановленої чинним законодавством процедури проведення податкового контролю чи провадження у справах про податкові правопорушення [4].

Базовою нормою ПК України, яка закріплює способи вирішення податкових спорів, є п. 56.1 ст. 56, де вказано, що рішення, прийняті контролюючим органом, можуть бути оскаржені в адміністративному або судовому порядку [2]. Варто акцентувати увагу на тому, що згідно з ч. 1 ст. 55 Конституції України права і свободи людини і громадянина захищаються судом [5]. Офіційне тлумачення ч. 1 зазначеної статті наведене у Рішенні Конституційного Суду України 
від 25.12.1997 р. № 9-зп, де вказано, що «частину першу статті 55 Конституції України треба розуміти так, що кожному гарантується захист прав і свобод у судовому порядку. Суд не може відмовити у правосудді, якщо громадянин України, іноземець, особа без громадянства вважають, що їхні права і свободи порушені або порушуються, створено або створюються перешкоди для їх реалізації або мають місце інші ущемлення прав та свобод. Відмова суду у прийнятті позовних та інших заяв, скарг, оформлених відповідно до чинного законодавства, $є$ порушенням права на судовий захист, яке згідно зі статтею 64 Конституції України не може бути обмежене» [6].

3 цього випливає, що у разі порушення контролюючим органом прав, свобод або законних інтересів особи - платника податків остання має право, не застосовуючи адміністративного способу оскарження рішень, дій або бездіяльності такого органу, звернутись за захистом своїх прав безпосередньо до суду. Наведені вище норми Конституції України та ПК України, які закріплюють право платника податків на оскарження рішень, дій або бездіяльності контролюючих органів шляхом звернення до суду, є матеріальним аспектом судових проваджень із вирішення податкових спорів, оскільки відсутність такого права нівелює можливість його захисту. Отже, першоосновою процесу $€$ право на його порушення.

Однак не тільки платник податків є особою, здатною порушити судовий адміністративний процес. Згідно 3 п. 5 ч. 1 ст. 19 КАС України, юрисдикція адміністративних судів поширюється на справи у публічно-правових спорах, зокрема: за зверненням суб'єкта владних повноважень у випадках, коли право звернення до суду для вирішення публічноправового спору надано такому суб'єкту законом [7]. Пункт 20.1 ст. 20 ПК України закріплює перелік прав контролюючих органів, серед яких, зокрема, й право на звернення до суду за наявності визначених цим пунктом підстав [2]. Тож право контролюючих органів на звернення до суду з адміністративним позовом стосовно платника податків за наявності визначених $n .20 .1 \mathrm{~cm} .20$ ПК України [2] підстав з метою захисту державних фінансових інтересів також слід віднести до матеріальних аспектів судових проваджень із вирішення податкових спорів.

Субординаційність як одна 3 головних ознак податкових правовідносин логічно зумовлює визначальну рису податкових спорів - публічний характер. Спеціалізація судів, своєю чергою, визначає їх предметну юрисдикцію. Галузевого нормативно-правового акта, спрямованого на врегулювання процесу iз розгляду податкових спорів, у нашій державі немає. Частина 1 ст. 18 Закону України «Про судоустрій та статус суддів» закріплюе спеціалізацію судів, однак податкових спорів як окремої категорії справ у переліку не передбачено. Натомість ст. 2 КАС України встановлює, що завданням адміністративного судочинства $є$ справедливе, неупереджене та своєчасне вирішення судом спорів у сфері публічно-правових відносин з метою ефективного захисту прав, свобод та інтересів фізичних осіб, прав та інтересів юридичних осіб від порушень з боку суб'єктів владних повноважень [7]. У аспекті цього варто також зазначити, що згідно 3 п. 2 ч. 1 ст. 4 КАС України публічно-правовим спором є спір, у якому, зокрема, хоча б одна сторона здійснює публічно-владні управлінські функції, в тому числі на виконання делегованих повноважень, і спір виник у зв'язку із виконанням або невиконанням такою стороною зазначених функцій [7]. Отже, наведені норми свідчать про те, що податкові спори $\epsilon$ видом публічно-правових спорів, тому їх розгляд здійснюється в адміністративних судах, а основним актом у регулюванні процесуальних аспектів вирішення подібних спорів є КАС України.

По суті, сам по собі публічно-правовий спір, сформований на основі матеріальних податкових правовідносин, який зацікавлені суб'єкти не вважають за доцільне вирішувати в адміністративному порядку, зумовлюе виникнення процесуальних правовідносин, тобто відносин із вирішення справи у судовому порядку.

Як встановлено у ст. 1 КАС України, цей Кодекс визначає юрисдикцію та повноваження адміністративних судів, встановлюе порядок здійснення судочинства в адміністративних судах [7]. Аналіз положень КАС України свідчить, що цей акт поряд із процесуальними нормами закріплює й матеріальні. Тож надалі варто зупинитись на дослідженні норм розглядуваного акта з метою виокремлення матеріальних та процесуальних.

Звичайно, більшість норм КАС України $€$ процесуальними. До таких норм належать ті, що:

1) визначають інстанційну, предметну, територіальну юрисдикцію судів (Глава 2 Розділ 1 КАС України);

2) процесуальний статус учасників справи, їх представників (Глава 4 Розділ 1 КАС України);

3) закріплюють основні положення про докази (Глава 5 Розділ 1 КАС України);

4) формулюють вимоги до процесуальних документів (ст. ст. 160-167, 296, 330 КАС України); 
5) регламентують порядок позовного адміністративного провадження, визначають його стадії та іх змістове наповнення (Глава 2-11 Розділу 2 КАС України);

6) регламентують порядок перегляду судових рішень шляхом апеляційного оскарження (Глава 1 Розділу 3 КАС України);

7) регламентують порядок перегляду судових рішень шляхом касаційного оскарження (Глава 2 Розділу 3 КАС України);

8) тощо.

Спірним є питання стосовно того, чи доцільно до процесуальних норм зараховувати норми, які встановлюють вимоги до процесуальних документів. У зв'язку із тим, що процесуальний документ як форма закріплення позиції сторони справи звернена до суду, складається з обов'язкових реквізитів, дотримання яких $є$ необхідною умовою прийняття їх судом, функціонально спрямований на «приведення у життя» процесу, то норми, що закріплюють вимоги до таких документів, слід відносити до процесуальних.

Глава 1 Розділу 1 «Загальні положення» КАС України в основному складається $з$ норм-принципів, норм-засад, нормдефініцій, норм-завдань. Це свідчить про те, що Глава 1 Розділу 1 містить переважно матеріальні норми.

Так, наприклад, із самої назви ст. 2 КАС України «Завдання та основні засади адміністративного судочинства» видається, що ця стаття предметно закріплює норми-засади та норми-завдання. Ці норми відіграють вагоме значення, зокрема, й у контексті судового порядку вирішення податкових спорів, оскільки вони (норми) спрямовані на визначення правових рамок процесу, закріплюють декларативні гарантії реалізації сторонами права на справедливе та неупереджене судочинство шляхом формування засад його здійснення.

Низка статей детально розкривають норми-засади, які зазначені у ст. 2 КАС України. Зокрема, до них належать:

1) ст. 6 «Верховенство права»;

2) ст. 8 «Рівність усіх учасників судового процесу перед законом і судом»;

3) ст. 9 «Змагальність сторін, диспозитивність та офіційне з'ясування всіх обставин у справі»;

4) ст. 10 «Гласність судового процесу»;

5)ст. 11 «Відкритість інформації щодо справи»;

6)ст. 13 «Право на перегляд справи та оскарження судового рішення»;

7)ст. 14 «Обов'язковість судових рішень».

Стаття 4 цього ж Кодексу містить визначення понять, якими оперує цей нормативно- правовий акт, тобто передбачає норми-дефініції. Щодо податкових спорів, то варто акцентувати увагу на таких термінах:

1) публічно-правовий спір - 3 цієї дефініції випливає висновок про те, що податковий спір за характером є публічно-правовим;

2) суб'єкт владних повноважень - до останніх належить і контролюючий орган;

3) позивач і відповідач визначають процесуальний статус платників податків та контролюючих органів як осіб, які мають право захищати свої права, свободи та інтереси, або реалізовувати свої повноваження, або ж відповідати за вимогами іншої сторони;

4) індивідуальний акт дає підстави віднести акти, які видаються контролюючими органами за результатами здійснення контрольних заходів, до категорії індивідуальних актів, що можуть бути оскаржені у порядку адміністративного судочинства.

До матеріальних норм, закріплених у КАС України, можна віднести норми, які закріплюють вимоги до «інших учасників судового процесу». Так, експертом може бути особа, яка володіє спеціальними знаннями, необхідними для з'ясування відповідних обставин справи (ч. 1 ст. 68 КАС України [7]). Як експерт з питань права може залучатися особа, яка має науковий ступінь та є визнаним фахівцем у галузі права (ч. 1 ст. 69 КАС України [7]). Спеціалістом $€$ особа, яка володіє спеціальними знаннями та навичками, необхідними для застосування технічних засобів, і призначена судом для надання консультацій та технічної допомоги під час вчинення процесуальних дій, пов'язаних із застосуванням таких технічних засобів (фотографування, складання схем, планів, креслень, відбору зразків для проведення експертизи тощо) (ч. 1 ст. 70 КАС України [7]). Перекладачем є особа, яка вільно володіє мовою, якою здійснюється адміністративне судочинство, та іншою мовою, знання якої необхідне для усного або письмового перекладу з однієї мови на іншу, а також особа, яка володіє технікою спілкування з глухими, німими чи глухонімими (ч. 1 ст. 71 КАС України [7]). У разі відповідності особи зазначеним вимогам, які, наприклад, ставляться до експерта, остання має право отримати відповідний процесуальний статус. Право особи займати відповідний правовий статус є матеріальним.

КАС України містить також норми, які мають змішану правову природу, тобто одна й та сама норма одночасно може розглядатись як матеріальна, так і процесуальна.

Наприклад, ч. 2 ст. 14 КАС України встановлює, що судові рішення, які набрали законної сили, є обов'язковими до виконання 
всіма органами державної влади, органами місцевого самоврядування, ї посадовими та службовими особами, фізичними і юридичними особами та їх об'єднаннями на всій території України [7]. Набрання законної сили судовим рішенням є завершальною стадією судового процесу. Таке рішення, як правило, не може бути оскаржене. Протягом п'яти днів 3 дня набрання рішенням законної сили суд, який розглядав справу, зобов'язаний направити стягувачу виконавчий лист. Після цього в особи, на користь якої рішення постановлене, виникає матеріальне право - порушити виконавче провадження. Завершення процесу й виникнення права на виконання рішення зумовлює двоєдину (матеріально-процесуальну) природу розглядуваної норми.

У аспекті вищенаведеного слід розглянути ч. 1 ст. 370 КАС України, де вказано, що судове рішення, яке набрало законної сили, є обов'язковим для учасників справи, для їхніх правонаступників, а також для всіх органів, підприємств, установ та організацій, посадових чи службових осіб, інших фізичних осіб і підлягає виконанню на всій території України, а у випадках, встановлених міжнародними договорами, згода на обов'язковість яких надана Верховною Радою України, або за принципом взаємності, - за їі межами [7]. По суті, ця норма змістовно тотожна тій, що закріплена ч. 2 ст. 14 КАС України, проте є розширеною. Однак визначальним моментом, з точки зору нашого дослідження, $є$ те, що ч. 1 ст. 370 КАС України міститься у Розділі 4 під назвою «Процесуальні питання, пов'язані з виконанням судових рішень в адміністративних справах». Тобто законодавець розглядувану норму відносить до процесуальної. На наш погляд, право сторони спору, на користь якої рішення постановлене, порушити виконавче провадження з метою виконання судового рішення та обов'язок зобов'язаної сторони виконати резолютивну частину такого рішення мають матеріальне підгрунтя, хоч і випливають із факту завершення судового процесу.

Окремо варто визначитись, чи можна норми стосовно такої вимоги до позовної заяви, як «зміст позовних вимог», у пї взаємозв'язку з видами рішень, які можуть приймати суди за результатами розгляду справ, відносити до процесуальних. Зміст позовних вимог, по суті, є предметом позову, який випливає із матеріальних правовідносин. Суд розглядає справу у межах позовних вимог, тому має можливість ухвалити одне з рішень, передбачених ч. 2 ст. 245 КАС України, тобто задовольнити або відмовити у задоволенні матеріальної вимоги. Тож, норми про таку вимогу до позовної заяви, як «зміст позовних вимог», яким кореспондують норми про види рішень, які можуть прийняти суди за результатами розгляду справ, є змішаними. 3 одного боку, вони фіксують матеріальну вимогу у позові, а 3 іншого $€$ складовою частиною процесуального документа, який породжує початок судового адміністративного процесу. Рішення судів, своєю чергою, задовольняють або не задовольняють матеріальну вимогу, завершуючи тим самим розгляд справи у відповідній інстанції.

\section{Список використаних джерел:}

1. Податкове право : навчальний посібник. / Г.В. Бех, О.О. Дмитрик, Д.А. Кобильнік та ін. ; За ред. проф. М.П. Кучерявенка. Київ : Юрінком Інтер, 2003. С. 13-14.

2. Податковий кодекс України в ред. від 29.12.2019. URL: https://zakon.rada.gov.ua/laws/ show/2755-17 (дата звернення: 23.01.2020).

3. Тильчик В.В. Поняття і суть податкових спорів між органами державної податкової служби та платниками податків. Часопис Київського університету права. № 3. 2010. С. 110-114.

4. Цветков И.В. Налогоплательщик в судебном процессе : практическое пособие по судебной защите. Москва : «Волтерс Клувер», 2004. 49 с.

5. Конституція України в ред. від 01.01.2020. URL: https://zakon.rada.gov.ua/laws/ show/254к/96-вр (дата звернення: 23.01.2020).

6. Рішення Конституційного Суду України від 25.12.1997 p. № 9-3п. URL: https://zakon.rada.gov. ua/laws/show/v009p710-97.

7. Кодекс адміністративного судочинства України в ред. від 01.01.2020. URL: https://zakon. rada.gov.ua/laws/show/2747-15 (дата звернення: 24.01.2020).

The author defines the content and correlation of material and procedural aspects within the framework of tax litigation proceedings, the purpose of substantive and procedural aspects of the settlement of tax disputes in court. Particular attention is paid to the study of the totality of tax dispute resolution procedures, regulated in detail by administrative procedural legislation, characterized by stability and interdependence. The peculiarities of tax litigation are determined. The classification of material aspects of the resolution of tax disputes according to the criterion of fixing the material aspects of court proceedings on the resolution of tax disputes in regulatory legal acts. In the course of the research the substantive content of the concept of "tax dispute" is determined, and also it is determined what actions can cause tax dispute, which subjects may be parties to such dispute, which authorities have the right to make a final decision in the conditions of settlement 
of legal conflict. The scientific study emphasized the existence of tax relations as the basic material aspect of litigation in the settlement of tax disputes, since in the absence of such relations between the parties to initiate the process is impossible. During the study of the concept of "tax dispute" and its main characteristics, a distinction was made between tax disputes under the criterion of jurisprudence into disputes on matters of law, factual disputes and procedural disputes. Considering the question of the adherence of certain norms to the procedural rules, the author concludes that there are rules in the tax legislation that have a mixed legal nature, that is, the same rule can be considered both substantive and procedural at the same time, since they have a material basis on the basis of this from the procedural facts.

Key words: tax disputes, court proceedings, material aspects of tax litigation, procedural aspects of tax litigation. 